EUROPEAN CENTRAL BANK

WORKING PAPER SERIES

NO. 3 I 5 / MARCH 2004

\title{
OPTION-IMPLIED ASYMMETRIES \\ IN BOND MARKET \\ EXPECTATIONS AROUND MONETARY POLICY ACTIONS OF THE ECB
}

RY
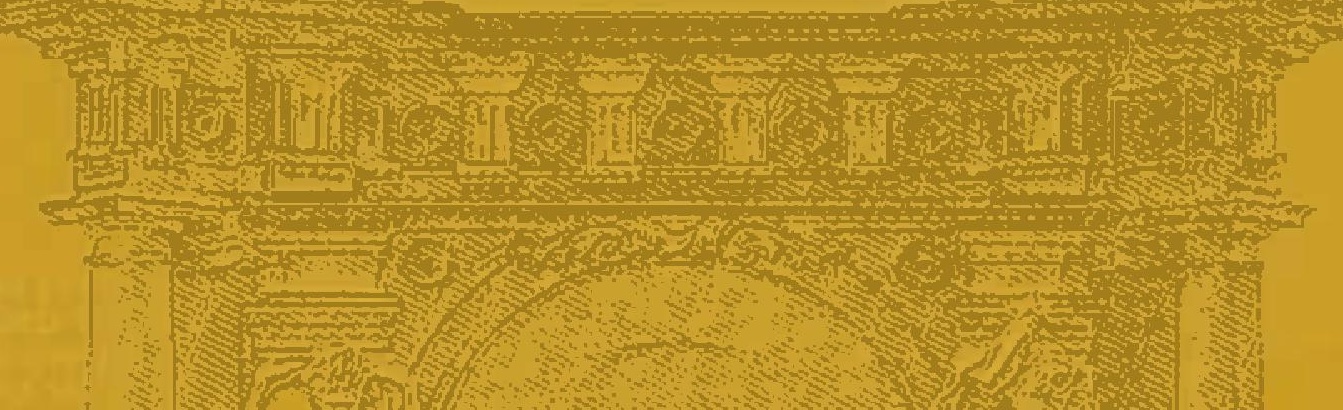


\author{
OPTION-IMPLIED \\ ASYMMETRIES \\ IN BOND MARKET \\ EXPECTATIONS \\ AROUND MONETARY \\ POLICY ACTIONS \\ OF THE ECB'
}

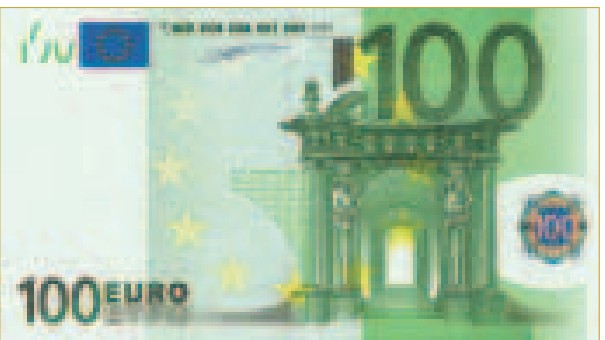

by Sami Vähämaa ${ }^{2}$

\title{
100느을
}

In 2004 all

publications

will carry

from the

$€ 100$ banknote.

This paper can be downloaded without charge from http://www.ecb.int or from the Social Science Research Network electronic library at http://ssrn.com/abstract_id $=515079$.

I Valuable comments by Magnus Andersson, Antonello D’Agostino, Emmanuel Davradakis, Manfred Kremer, Elizaveta Krylova, Jussi Nikkinen, Elias Papaioannou, Seppo Pynnönen, an anonymous referee, and seminar participants at the European Central Bank

are gratefully acknowledged.This paper was prepared while the author was visiting the Capital Markets and Financial Structure Division of the ECB. The views expressed in this paper are those of the author and do not necessarily reflect the views of the European Central Bank.

2 Contacts: University of Vaasa, Department of Accounting and Finance, P.O. Box 700, FIN-65 I 0 I Vaasa, Finland; Tel. +358 6324 8197; Fax: +358 6324 8344; email: sami@uwasa.fi. 


\section{드 European Central Bank, 2004}

\section{Address}

Kaiserstrasse 29

60311 Frankfurt am Main, Germany

Postal address

Postfach 160319

60066 Frankfurt am Main, Germany

Telephone

+496913440

\section{Internet}

http://www.ecb.int

Fax

+496913446000

Telex

411144 ecb d

All rights reserved.

Reproduction for educational and noncommercial purposes is permitted provided that the source is acknowledged.

The views expressed in this paper do not necessarily reflect those of the European Central Bank.

The statement of purpose for the ECB Working Paper Series is available from the ECB website, http://www.ecb.int.

ISSN 1561-0810 (print)

ISSN 1725-2806 (online) 


\section{CONTENTS}

Abstract 4

Non-technical summary 5

1. Introduction 7

2. Data 10

3. Extracting asymmetries in market expectations from option prices

4. Monetary policy actions and asymmetries in bond market expectations

5. Conclusions

References

European Central Bank working paper series 


\begin{abstract}
This paper uses data on German government bond futures options to examine the behaviour of market expectations around monetary policy actions of the European Central Bank (ECB). In particular, this paper focuses on the asymmetries in bond market expectations, as measured by the skewness of option-implied probability distributions of future bond yields. The results show that market expectations are systematically asymmetric around monetary policy actions of the ECB. Around monetary policy tightening, option-implied yield distributions are positively skewed, indicating that market participants attach higher probabilities for sharp yield increases than for sharp decreases. Correspondingly, around loosening of the policy, implied yield distributions are negatively skewed, suggesting that markets assign higher probabilities for sharp yield decreases than for increases. Furthermore, the results indicate that market expectations are significantly altered around monetary policy actions, as asymmetries in market expectations tend to increase before changes in the monetary policy stance, and to decrease afterwards.
\end{abstract}

JEL classification: E44; E52; G10; G13

Keywords: market expectations, asymmetries, implied skewness, monetary policy 


\section{NON-TECHNICAL SUMMARY}

This paper examines the behaviour of asymmetries in bond market expectations around monetary policy actions of the European Central Bank (ECB). Although not directly observable, these market expectations are implicit in the market prices of options. For instance, the price of a call option depends on the probability of the underlying asset price exceeding the strike price of the option. Consequently, a set of option prices with the same maturity but with different strike prices can be used to infer the entire probability distribution of the underlying asset price. This paper uses data on German government bond futures options to examine the behaviour of asymmetries in market expectations around monetary policy actions of the ECB. The asymmetries in market expectations are assessed by focusing on the skewness of option-implied probability distributions of future bond yields.

A priori, it is expected that market expectations are systematically asymmetric around changes in the monetary policy stance. The reasoning for this is the essentially asymmetric action set of the central bank. During restrictive monetary policy periods, market participants know that the reference interest rates are either increased or kept unchanged in a given monetary policy meeting. Similarly, in an expansive monetary policy environment, market participants know that the central bank will either reduce the interest rates or keep them unchanged. In addition, given that the market participants tend to anticipate the timing of monetary policy actions, but not necessarily the exact impact of the action on asset prices, market expectations are likely to be prominently asymmetrically dispersed.

The results of this paper show that market expectations are systematically asymmetric around monetary policy actions of the ECB. Around monetary policy tightening, option-implied yield distributions are positively skewed, indicating that market participants attach higher probabilities for sharp yield increases than for sharp decreases. Correspondingly, around loosening of the policy, implied yield distributions are negatively skewed, suggesting that markets assign higher probabilities for sharp yield decreases than for increases. These results are reasonable, given the essentially asymmetric action set of the central bank during expansive and restrictive monetary policy periods. 
Furthermore, the results of this analysis indicate that market expectations are significantly altered around monetary policy actions of the ECB. The results shows that the asymmetries in market expectations tend to increase before changes in the monetary policy stance, and to decrease afterwards. This suggests that market participants are inclined to anticipate monetary policy shifts. Finally, the results indicate that asymmetries in bond market expectations may be utilised in predicting monetary policy actions of the ECB.

In general, the results of this paper show that option-implied asymmetries can provide useful insight into market expectations. These results may be of interest, for instance, to central banks, as the assessment of possible asymmetries in market expectations may provide useful complementary information for the purposes of formulating monetary policy and, additionally, for assessing the timing of monetary policy actions. 


\section{INTRODUCTION}

Considerable advances in extracting market expectations from financial asset prices have occurred during the last ten years (see Söderlind and Svensson, 1997 for a survey). Traditionally, market expectations of future interest rates, for instance, have been extracted from the term structure of interest rates or from futures contracts on money market instruments and bonds. A severe limitation of these measures is that they reflect only central expectations, and hence provide no indication about the dispersion of market expectations. Consequently, the focus has recently started to shift to information contained in option prices.

Volatility implied by option prices is now widely considered to be a useful forward-looking measure of market uncertainty, and is therefore used extensively among market participants and central banks to assess the uncertainty surrounding central expectations. Option prices, however, may reveal considerable information beyond implied volatility. For instance, a call option has a positive payoff only if the price of the underlying asset at the maturity of the option exceeds the strike price of the option. The call option price should therefore reflect market expectations about the probability of the underlying asset price exceeding the strike price of the option. Hence, a set of option prices with the same maturity but with different strike prices can be used to extract the entire probability distribution of the underlying asset price at the maturity of the option.

Option-implied probability distributions have gained a lot of attention over recent years. Central banks, in particular, are now increasingly using option-implied distributions to evaluate market expectations of future interest rates and exchange rates, and using these expectations as complementary information for the purposes of formulating monetary policy. ${ }^{1}$ Several alternative methods for extracting probability distributions from option prices have been proposed in the literature. Reviews of different techniques are provided in Bahra (1997), Jackwerth (1999), and Bliss and

\footnotetext{
${ }^{1}$ A substantial proportion of the research on option-implied distributions has been conducted in central banks. Recent examples of central bank research include Bahra (1997), Melick and Thomas (1997), Hördahl (2000), Bliss and Panigirtzoglou (2002), Glatzer and Scheicher (2003), Hördahl and Vestin (2003), Bliss and Panigirtzoglou (2004), and Panigirtzoglou and Skiadopoulos (2004).
} 
Panigirtzoglou (2002), while Campa et al. (1998) and Jondeau and Rockinger (2000) provide comparisons of alternative methods. A number of papers have used optionimplied probability distributions to examine the behaviour of market expectations around specific events, such as macroeconomic news announcements (e.g., Beber and Brandt, 2003), financial crises (e.g., Melick and Thomas, 1997; Gemmill and Saflekos, 2000; Söderlind, 2000), elections (e.g., Gemmill et al., 2000, Coutant et al., 2001), and central bank interventions (e.g., Cooper and Talbot, 1999; Galati and Melick, 2002). These studies show that option-implied distributions are useful for assessing market expectations around economic events. ${ }^{2}$ Moreover, implied distributions can be used to gauge changes in market expectations and, additionally, to reveal possible asymmetries in expectations.

This paper uses data on German government bond futures options to examine the behaviour of market expectations around monetary policy actions of the European Central Bank (ECB). In particular, this paper focuses on the asymmetries in bond market expectations, as measured by the skewness of option-implied probability distributions of future bond yields. By focusing on the behaviour of asymmetries in bond market expectations, this paper provides new evidence on the impact of monetary policy actions on financial markets.

The existing literature on the impact of monetary policy actions on financial markets is extensive. Several papers document that monetary policy actions of central banks systematically affect money market interest rates, bond yields, and stock prices (see e.g., Neumann and Weidmann, 1998; Kuttner, 2001; Lee, 2002; Bomfim, 2003; Gasbarro and Monroe, 2004). ${ }^{3}$ In addition, studies such as Jensen et al. (1996), Thorbecke (1997), and Johnson et al. (2003) show that stock and bond returns are significantly different during expansive and restrictive monetary policy periods. Optionimplied probability distributions and monetary policy decisions have previously been combined in Bhar and Chiarella (2000) and Mandler (2003). Bhar et al. (2000) investigate the behaviour of option-implied distributions of short-term interest rates

\footnotetext{
${ }^{2}$ Gemmill et al. (2000), however, conclude that although implied distributions are useful for revealing the market sentiment, they do not have much power for forecasting future events.

${ }^{3}$ Note that the reverse impact may also occur, as monetary policy makers may respond to asset price developments (see Gilchrist and Leahy, 2002 for a review).
} 
around four interest rate reductions conducted by the Reserve Bank of Australia. They find that the probability of a decline in interest rates increases before the actual central bank rate reductions, suggesting that market participants anticipate the forthcoming interest rate cut. Mandler (2003) focuses on the impact of the ECB's monetary policy meetings on implied distributions of short-term interest rates. He shows that the monetary policy meetings of the ECB tend to decrease the uncertainty in market expectations. $^{4}$

This paper differs from Bhar et al. (2000) and Mandler (2003) in several respects. First, Bhar et al. (2000) conduct case studies around four monetary policy actions, while this paper provides a more systematic investigation by using a longer data period, which includes several monetary policy shifts. Second, while Bhar et al. (2000) use implied distributions to assess the probability of a decline in interest rates before monetary policy actions, this paper focuses on the asymmetries of implied distributions. Third, Mandler (2003) investigates the impact of monetary policy meetings, regardless of whether the monetary policy stance is actually changed or not, on option-implied probability distributions. This paper differs from Mandler (2003) by focusing solely on the impact of monetary policy actions. Finally, Bhar et al. (2000) and Mandler (2003) use nonparametric volatility smile smoothing techniques (à la Shimko, 1993) to estimate the option-implied distributions. In this paper, option-implied probability distributions are extracted based on a parametric approach, which assumes that the distribution of the underlying asset price at the maturity of the option is a mixture of two lognormal distributions. This approach may be considered theoretically more competent as it ensures proper behaviour of the tail probabilities. ${ }^{5}$

This paper contributes to the literature on the impact of monetary policy actions on financial markets by focusing on the asymmetries in bond market expectations as

\footnotetext{
${ }^{4}$ Consistently, Nikkinen and Sahlström (2004) find that implied volatility tends to be reduced by the Federal Open Market Committee (FOMC) meetings.

${ }^{5}$ Campa et al. (1998) show that the mixture of lognormals technique and the approach based on volatility smile smoothing produce virtually identical implied distributions while Bliss and Panigirtzoglou (2002) document the nonparametric technique to be more robust. However, the mixture of lognormals approach is theoretically more appealing as it ensures smooth behaviour of the tails, and most importantly, precludes negative tail probabilities.
} 
reflected in option-implied probability distributions of future bond yields. It is hypothesized here that market expectations are systematically asymmetric around changes in the monetary policy stance. The reasoning for this is the essentially asymmetric action set of the central bank. During restrictive monetary policy periods, market participants know that the reference interest rates are either increased or kept unchanged in a given monetary policy meeting. Similarly, in an expansive monetary policy environment, market participants know that the central bank will either reduce the interest rates or keep them unchanged. In addition, given that the market participants tend to anticipate the timing of monetary policy actions (e.g., Perez-Quiros and Sicilia, 2002), but not necessarily the exact impact of the action on asset prices, ${ }^{6}$ market expectations are likely to be prominently (asymmetrically) dispersed. Therefore, it is expected that around monetary policy tightening, option-implied yield distributions are positively skewed, indicating that market participants attach higher probabilities for sharp yield increases than for sharp decreases. Similarly, implied yield distributions are expected to be negatively skewed around loosening of the policy, implying that markets assign higher probabilities for sharp yield decreases than for increases.

The remainder of the paper is organized as follows. Section 2 describes the bond futures options data used in the empirical analysis. The methodology used to extract asymmetries in market expectations from option prices is presented in Section 3. In Section 4, the empirical findings on the behaviour of asymmetries in market expectations around monetary policy actions of the ECB are reported. Finally, Section 5 offers concluding remarks.

\section{DATA}

The empirical analysis in this paper is performed using daily settlement prices of options on short-term German government bond futures traded at Eurex. The bond underlying the futures contract is Bundesschatzanweisungen (Schatz), a notional

\footnotetext{
${ }^{6}$ Note that although the impact of a monetary policy action on short-term money market rates may be correctly anticipated, the exact impact of the action on bond yields and stock prices is likely to be unknown.
} 
German government bond with 6 percent coupon and maturity of $1 \frac{3 / 4}{4}$ to $2 \frac{1}{4}$ years. The settlement prices for the Schatz futures and futures options are obtained from Eurex. The sample period used in the analysis extends from July 1999 to July 2003. During this period, the minimum bid rate used in the main refinancing operations of the ECB was changed 14 times.

German government bond derivatives are commonly regarded as the benchmark for the euro area yield curve. The options on German government bond futures traded at Eurex are ideal for deriving implied distributions, since a wide range of strike prices is continuously available for trading. Moreover, the high liquidity of the options and the underlying futures contracts ensures that the prices of these derivatives instruments reasonably accurately reflect the information set available to financial markets. ${ }^{7}$

The options on Schatz futures are American-style. However, due to the futuresstyle margining procedure, these options are actually priced as European options, and hence, the option prices do not include premium for the early exercise possibility (see Chen and Scott, 1993 and Bahra, 1997 for further discussion). The expiration months for the Schatz futures options are the three nearest calendar months as well as the following month within the quarterly expiration cycle of March, June, September, and December. The Schatz futures contracts expire in March, June, September, and December. The underlying contract for the options expiring in the quarterly expiration cycle months is the futures contract expiring in the same month. For other expiration months, the underlying contract is the next maturing futures contract in the quarterly expiration cycle. The Schatz futures options expire six trading days before the first calendar day of the contract month.

Three filtering constraints are imposed to the complete option data set. First, in order to avoid expiration-related unusual price and volume fluctuations, options with less than 5 trading days to maturity are excluded from the sample. Second, only at-themoney (ATM) and out-of-the-money (OTM) options are used in the empirical analysis. In-the-money (ITM) options are discarded because they are less liquid than OTM and

\footnotetext{
${ }^{7}$ German government bond futures and futures options are the most liquid exchange-traded derivatives in the world. Their daily trading volumes exceed the volumes of the corresponding U.S. Treasury Note derivatives.
} 
ATM options, and because by using both OTM call and put options it can be ensured that the complete strike price spectrum is efficiently utilised in the estimation of implied distributions. Finally, options for which the quoted settlement price equals the minimum possible price quotation are discarded, as their prices are uninformative and unreliable. Altogether 116,186 option price observations satisfy the sampling criteria.

\section{EXTRACTING ASYMMETRIES IN MARKET EXPECTATIONS FROM OPTION PRICES}

The price of a call option, $c$, written on a (bond) futures contract $F$, equals the discounted expected value of the option's payoff function, $\max [F-K, 0]$, where $K$ denotes the strike price of the option, and the expectations of the payoff function are taken with respect to the risk-neutral probability measure. Therefore, the price of a European call option at time $t$, with expiration date $T$, can be written as

$$
c=e^{-r(T-t)} \int_{K}^{\infty} f\left(F_{T}\right)\left(F_{T}-K\right) d F_{T}
$$

where $f\left(F_{T}\right)$ denotes the risk-neutral probability density function ${ }^{8}$ of the underlying asset price at the maturity of the option, and $r$ is the risk-free interest rate. Analogously, the price of a put option equals the discounted expected value of the payoff function, $\max [K-F, 0]$, and hence, the price of a European put option, $p$, can be expressed as

$$
p=e^{-r(T-t)} \int_{0}^{K} f\left(F_{T}\right)\left(K-F_{T}\right) d F_{T} .
$$

\footnotetext{
${ }^{8}$ The risk-neutral probability distribution may differ from the objective distribution. Risk-neutrality, however, should mainly affect the location of the distribution, and influence the distributional shape only negligibly (see e.g., Rubinstein, 1994).
} 
Since the option price is a function of the risk-neutral density function, $f\left(F_{T}\right)$, a set of option prices observable in the market can be used to extract this density. In principle, the density function may take any functional form. In practice, however, finite variance distributions which are stable under addition are the only reasonable candidates. Applying the lognormal distribution to Equations (1) and (2), for instance, leads to the Black-Scholes (1973) model.

Given that financial asset price distributions are in the neighbourhood of the lognormal distribution, Ritchey (1990), Melick and Thomas (1997), Bahra (1997), Campa et al. (1998), Gemmill and Saflekos (2000), and Söderlind (2000), among others, assume that the risk-neutral density function of the underlying asset price is a mixture of lognormal densities. This approach is relatively flexible in the sense that a wide variety of distributional shapes can be approximated by a mixture of lognormal distributions. ${ }^{9}$

Assume the density function of the underlying asset price at the maturity of the option to be a linear combination of two lognormal density functions

$$
f\left(F_{T}\right)=\omega L\left(\alpha_{1}, \beta_{1}, F_{T}\right)+(1-\omega) L\left(\alpha_{2}, \beta_{2}, F_{T}\right)
$$

where $L(\cdot)$ denotes the lognormal density function, $\alpha_{i}$ and $\beta_{i}$ are the location and dispersion parameters for the lognormal density $i$, respectively, and $\omega$ is a weighting parameter. Under the mixture of lognormals assumption, Equations (1) and (2) can be rewritten as

$$
\begin{gathered}
c=e^{-r(T-t)} \int_{K}^{\infty}\left[\omega L\left(\alpha_{1}, \beta_{1}, F_{T}\right)+(1-\omega) L\left(\alpha_{2}, \beta_{2}, F_{T}\right)\right]\left(F_{T}-K\right) d F_{T} \\
p=e^{-r(T-t)} \int_{0}^{K}\left[\omega L\left(\alpha_{1}, \beta_{1}, F_{T}\right)+(1-\omega) L\left(\alpha_{2}, \beta_{2}, F_{T}\right)\right]\left(K-F_{T}\right) d F_{T} .
\end{gathered}
$$

\footnotetext{
${ }^{9}$ The approach based on a mixture of lognormals allows for arbitrary asymmetries and multimodality in the option-implied distribution.
} 
Bahra (1997) derives closed-form solutions to Equations (4) and (5). The closedform option pricing formulas for European call and put options on (bond) futures are given by ${ }^{10}$

$$
\begin{aligned}
& c=\omega\left[e^{\alpha_{1}+\frac{1}{2} \beta_{1}^{2}} \Phi\left(d_{1}\right)-K \Phi\left(d_{1}-\beta_{1}\right)\right]+(1-\omega)\left[e^{\alpha_{2}+\frac{1}{2} \beta_{2}^{2}} \Phi\left(d_{2}\right)-K \Phi\left(d_{2}-\beta_{2}\right)\right] \\
& p=\omega\left[-e^{\alpha_{1}+\frac{1}{2} \beta_{1}^{2}} \Phi\left(-d_{1}\right)+K \Phi\left(\beta_{1}-d_{1}\right)\right]+(1-\omega)\left[-e^{\alpha_{2}+\frac{1}{2} \beta_{2}^{2}} \Phi\left(-d_{2}\right)+K \Phi\left(\beta_{2}-d_{2}\right)\right]
\end{aligned}
$$

where

$$
d_{1}=\frac{-\ln K+\alpha_{1}+\beta_{1}^{2}}{\beta_{1}}, d_{2}=\frac{-\ln K+\alpha_{2}+\beta_{2}^{2}}{\beta_{2}}
$$

and $\Phi(\cdot)$ denotes the cumulative standard normal distribution function. The existence of closed-form option pricing formulas obviates the need for numerical integration, and thus, ensures greater accuracy in the estimation of option-implied risk-neutral density functions.

In this paper, Equations (6) and (7) are applied to estimate the unobserved distributional parameters, $\theta=\left\{\alpha_{1}, \alpha_{2}, \beta_{1}, \beta_{2}, \omega\right\}$, for the mixture density from a set of option prices. The distributional parameters are estimated by minimizing the sum of squared deviations between the observed market prices, $\hat{c}$ and $\hat{p}$, and theoretical option prices, $c$ and $p$, given by Equations (6) and (7)

$$
\min _{\theta} \sum_{i=1}^{m}\left[\hat{c}_{i}-c_{i}(\theta)\right]^{2}+\sum_{i=1}^{n}\left[\hat{p}_{i}-p_{i}(\theta)\right]^{2}
$$

\footnotetext{
${ }^{10}$ Black's (1976) version of the Black-Scholes (1973) formula is the corresponding single lognormal model.
} 
where $m$ and $n$ denote the number of call and put price observations on a given day for a given maturity class, respectively. Once the distributional parameters have been estimated, the option-implied risk-neutral probability distribution of the underlying asset price at the maturity of the option can be constructed. Initially, option-implied distribution of the bond futures price is obtained. Since results in terms of yield to maturity may be more informative and intuitive, the estimated bond futures price distribution, $f\left(F_{T}\right)$, is subsequently transformed into a bond yield distribution, $f\left(y_{T}\right)$, using an approximation based on modified duration and convexity.

Asymmetries in market expectations are quantified as the skewness of optionimplied probability distribution of future bond yields. Option-implied skewness, $\xi$, is defined as the standardized third central moment of the option-implied yield distribution

$$
\xi=\frac{\mathrm{E}\left[\left[y_{T}-\mathrm{E}\left(y_{T}\right)\right]^{3}\right]}{\mathrm{E}\left[\left[y_{T}-\mathrm{E}\left(y_{T}\right)\right]^{2}\right]^{\frac{3}{2}}} .
$$

Option-implied skewness is estimated from the bond futures options data for each trading day in the data set, and for each maturity of option contracts on a given day. In order to avoid spurious inference due to time-to-maturity effects of options, a timeseries of implied skewness with a constant maturity of 30 days is constructed. The constant maturity time-series is obtained by linear interpolation between two adjacent maturity skewness estimates. The three shortest maturity option contracts are used as follows. The shortest and the second shortest option contracts are used until the second shortest has 30 days to maturity. Thereafter, the second and the third shortest option contracts are used until the expiry of the shortest contract. The changes in the constant maturity implied skewness over time should purely reflect changes in market expectations. Finally, in order to minimize the unavoidable estimation errors in the skewness series, the daily data on constant maturity implied skewness are averaged into a weekly data set. The resulting data set is comprised of 213 time-series observations of option-implied skewness. 


\section{MONETARY POLICY ACTIONS AND ASYMMETRIES IN BOND MARKET EXPECTATIONS}

Figure 1 plots the developments in the option-implied skewness of short-term bond yields over the period from July 1999 until July 2003. During this period, the monetary policy stance of the ECB was changed 14 times. The upward arrows in Figure 1 denote the weeks when the minimum bid rate used on the main refinancing operations of the ECB was raised and downward arrows the weeks when the minimum bid rate was reduced. Several interesting features can be noted from Figure 1. On average, the implied yield distribution is almost symmetric, with a mean skewness estimate of 0.03 . However, it is apparent from Figure 1 that there are considerable asymmetries in market expectations. In addition, Figure 1 indicates that these asymmetries are varying heavily over time, with long periods of positive skewness during the first part of the sample period followed by long periods of considerable negative skewness during the latter part.

Interestingly, the major trends in the economic outlook can be easily identified from the implied skewness series, suggesting that the asymmetries in market expectations are closely related to developments in the economic fundamentals. During the exceptionally optimistic growth period from July 1999 until the end of 2000, implied skewness was constantly positive, and then dropped to levels below zero, implying a sudden change in market participants' expectations from attaching higher probabilities for sharp yield increases to instead attaching higher probabilities for declines in bond yields. This sudden drop in skewness at the end of 2000 is concurrent with the increased uncertainty regarding global, and especially U.S. economic growth prospects. As the euro area economic growth also started to slow down in the second quarter of 2001, skewness declined even further, and reached the bottom in the aftermath of the September $11^{\text {th }}$ terrorist attack. The most negative spike in the skewness series occurred in the beginning of November 2001, about two months after the September $11^{\text {th }}$ events and one week before the ECB loosened the stance of the monetary policy. 
Figure 1. Option-implied skewness and monetary policy actions of the ECB.

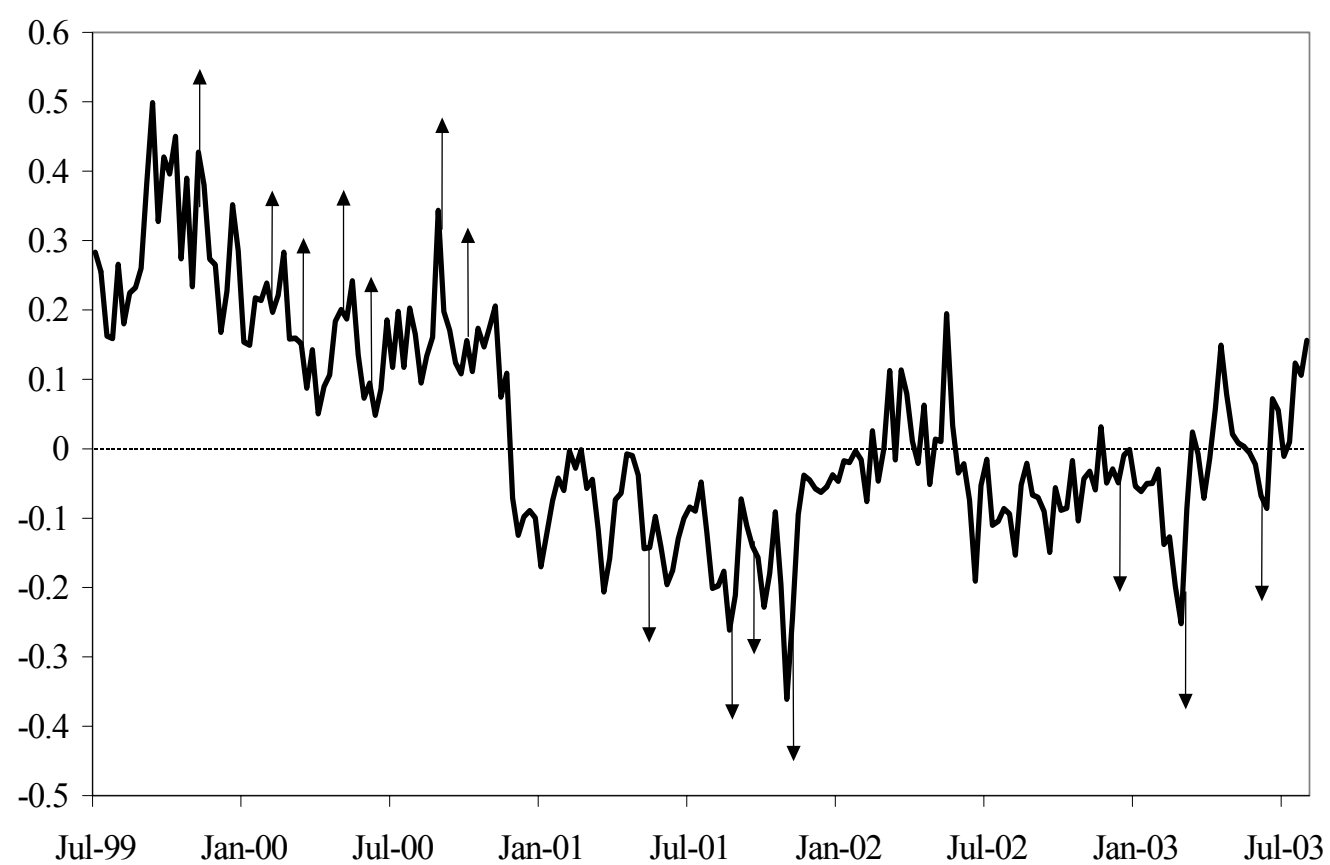

As the expectations of economic recovery increased in the spring of 2002, also skewness increased, and started to wander around zero. However, already during the second half of 2002 skewness again became more negative, perhaps in response to the downward revised economic forecasts at that time. The decline in skewness in the spring of 2003 is contemporaneous with the subdued economic activity and the Iraq crisis. Overall, Figure 1 suggests that implied skewness tends to be positive when there is a positive outlook for economic growth while during periods of sluggish growth prospects skewness appears to be negative.

Turning the focus onto the impact of monetary policy actions on the asymmetries in bond market expectations, Figure 1 shows a striking feature. Implied skewness has always been positive when the ECB has tightened the stance of the monetary policy, and negative when the monetary policy has been loosened. Table 1 reports descriptive statistics of implied skewness for the complete sample, for the weeks in which the monetary policy stance was loosened, and for the weeks in which the monetary policy stance was tightened. The descriptive statistics in Table 1 confirm that skewness has been high and positive, with an average skewness estimate of 0.20 , in the weeks when 
Table 1. Option-implied skewness and changes in the monetary policy stance.

The table reports summary statistics of option-implied skewness for the complete sample and for the weeks when the stance of the monetary policy was loosened or tightened. The confidence bounds for the mean estimates (reported in parentheses) are obtained via bootstrapping.

\begin{tabular}{lrrr}
\hline & All Weeks & Loosening & Tightening \\
\hline Mean & 0.031 & -0.132 & 0.200 \\
95\% Conf. Bound & {$[0.010 .0 .053]$} & {$[-0.186 .-0.081]$} & {$[0.148 .0 .258]$} \\
Median & -0.010 & -0.141 & 0.184 \\
Standard Deviation & 0.157 & 0.078 & 0.081 \\
Minimum & -0.361 & -0.245 & 0.094 \\
Maximum & 0.499 & -0.029 & 0.343 \\
\hline
\end{tabular}

the minimum bid rate used on the main refinancing operations of the ECB was raised, and low and negative, with an average skewness estimate of -0.14 , in the weeks when the minimum bid rate was reduced. The bootstrapped confidence bounds for the mean estimates (reported in parentheses) indicate that the observed differences in implied skewness are statistically highly significant. To illustrate these findings, Figure 2 plots two implied yield distributions with different levels of skewness. ${ }^{11}$ The other distribution corresponds to an average implied distribution in the weeks in which the monetary policy stance was tightened (skewness of 0.20 ), and the other to an average distribution in the weeks in which the policy stance was loosened (skewness of $-0.14)$.

Overall, Figure 1 together with Table 1 clearly demonstrate that the level of implied skewness is significantly different during expansive and restrictive monetary policy periods. During expansive monetary policy periods, market participants seem to assign higher probabilities for sharp yield decreases than for sharp increases. Analogously, market participants appear to attach higher probabilities for sharp yield increases than for sharp decreases during restrictive monetary policy periods.

${ }^{11}$ Mean, volatility, and kurtosis of the plotted distributions are set equal in order to facilitate comparison. 
Figure 2. Option-implied bond yield distributions.

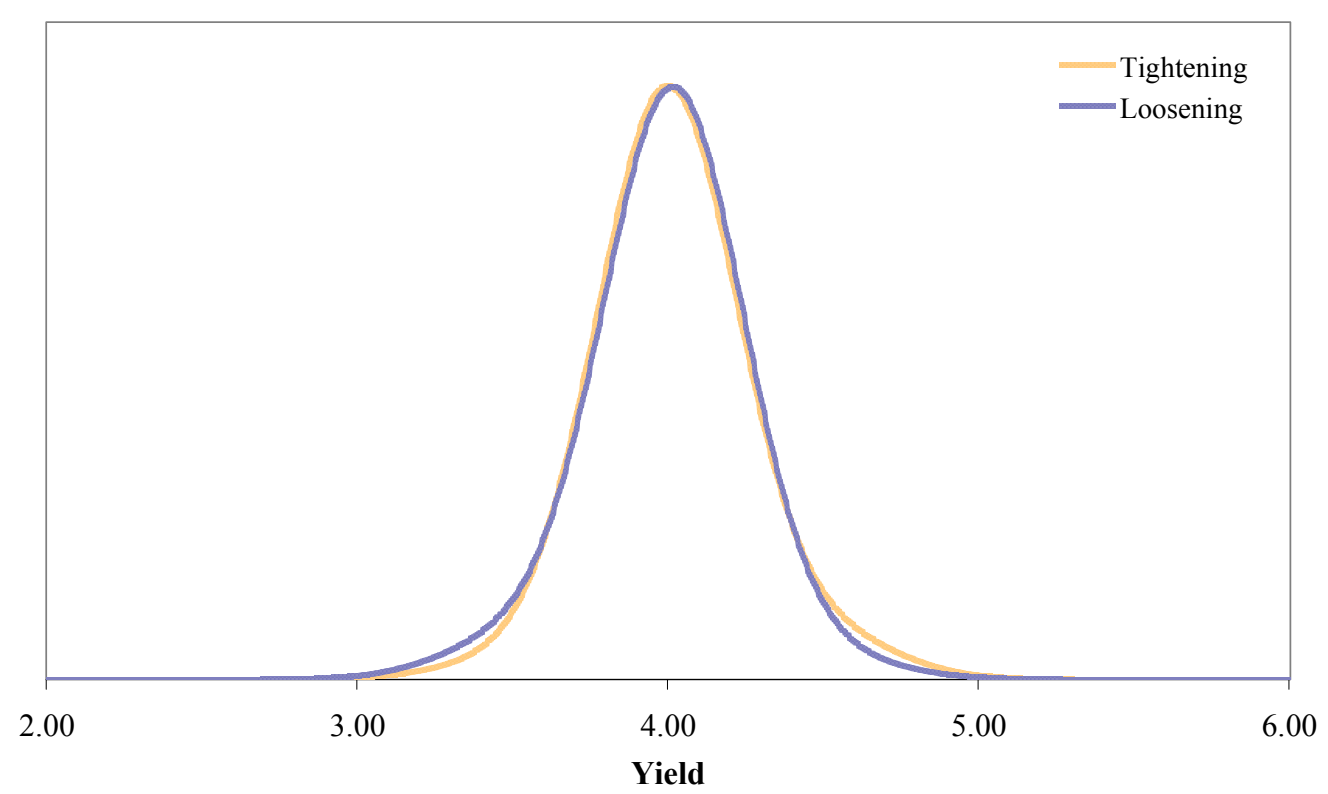

Figure 1 also reveals that most of the changes in the minimum bid rate have coincided with a spike in implied skewness, suggesting that the asymmetries in market expectations are significantly altered around monetary policy actions. To investigate whether there are systematic changes in implied skewness around changes in the monetary policy stance, changes in skewness are regressed on a set of dummy variables which identify the weeks before and after monetary policy actions. Figure 1 would suggest that implied skewness decreases before the stance of the monetary policy is loosened and increases afterwards, and correspondingly, increases before monetary policy is tightened and decreases afterwards. To ascertain the behaviour of asymmetries in market expectations around monetary policy actions, the following regression model is estimated

$$
\Delta S K E W_{t}=\alpha+\beta_{1} D E C_{t}^{-}+\beta_{2} D E C_{t}^{+}+\beta_{3} I N C_{t}^{-}+\beta_{4} I N C_{t}^{+}+\varepsilon_{t}
$$

where $S K E W_{t}$ denotes option-implied skewness at time $t$, and $D E C^{-}, D E C^{+}, I N C^{-}$, and $I N C^{+}$are dummy variables identifying the weeks before and after the monetary policy stance is loosened and tightened, respectively, and $\Delta$ is the first difference operator. 
The Breusch-Godfrey LM test indicates significant serial correlation in the residuals of this regression specification. In order to kill the residual serial correlation, an AR(2) error structure is specified. Model diagnostics suggest that this specification is adequate.

The estimation results of Equation (10) are reported in Table 2. The signs of the estimated regression coefficients are as expected, being negative for the $D E C^{-}$and $I N C^{+}$dummies and positive for the $D E C^{+}$and $I N C^{-}$dummies. This suggests that implied skewness decreases (i.e., becomes more negative) on the week before the stance of the monetary policy is loosened, and returns to a more normal level on the week after the change in the policy. Correspondingly, implied skewness seems to increase on the week before monetary policy tightening, and to decrease afterwards. The estimated coefficients for the monetary policy loosening dummies are statistically highly significant. However, the coefficients for the policy tightening dummies are statistically indistinguishable from zero. The model diagnostics reported in Table 2 show that the estimated model is well specified. The Breusch-Godfrey LM test and Engle's LM test indicate that there is no serial correlation left in the residuals, neither in the squared residuals. Moreover, the model diagnostics show that the residuals are homoskedastic and normally distributed.

As Figure 1 together with the estimation results in Table 2 indicate that the market expectations tend to become more asymmetric before monetary policy actions, it is of interest to examine whether asymmetries in bond market expectations can be utilised in predicting policy changes. To investigate whether changes in option-implied skewness have explanatory power for future changes in the monetary policy stance, limited dependent variable modelling is applied. It is expected here that market participants anticipate the forthcoming change in the monetary policy stance, and that this anticipation is shown in market expectations as increased asymmetry. This increased asymmetry in bond market expectations, in turn, is expected to provide a signal of the forthcoming monetary policy action. ${ }^{12}$

\footnotetext{
${ }^{12}$ However, it should be noted that in addition to monetary policy actions, asymmetries in bond market expectations may also be significantly affected by macroeconomic fundamentals (see Beber and Brandt, 2003), and hence, the forecasting exercise should be taken with some caution.
} 
Table 2. Parameter estimates of the dummy regression.

The table reports the parameter estimates of the following regression specification:

$\triangle S K E W_{t}=\alpha+\beta_{1} D E C_{t}^{-}+\beta_{2} D E C_{t}^{+}+\beta_{3} I N C_{t}^{-}+\beta_{4} I N C_{t}^{+}+\varepsilon_{t}$

where $S K E W_{t}$ denotes option-implied skewness at time $t$, and $D E C^{-}, D E C^{+}, I N C^{-}$, and $I N C^{+}$ are dummy variables identifying the weeks before and after the monetary policy stance is loosened and tightened, respectively, and $\Delta$ is the first difference operator. The reported model diagnostics are the Breusch-Godfrey LM test for residual serial correlation, Engle's LM test for ARCH in residuals, White's heteroskedasticity test, and the Jarque-Bera statistic for normality of residuals.

\begin{tabular}{lrrr}
\hline & Estimate & S.E. & $t$-stat. \\
\hline$\alpha$ & 0.000 & 0.004 & -0.131 \\
$\beta_{1}$ & $-0.057^{\dagger}$ & 0.026 & -2.189 \\
$\beta_{2} \dagger_{3}$ & $0.0655^{\dagger}$ & 0.026 & 2.494 \\
$\beta_{4}$ & 0.005 & 0.026 & 0.180 \\
$\mathrm{AR}(1)$ & -0.005 & 0.026 & -0.207 \\
$\mathrm{AR}(2)$ & $-0.307 \ddagger$ & 0.070 & -4.384 \\
& $-0.146^{\dagger}$ & 0.069 & -2.096 \\
LM Test & & & \\
ARCH LM Test & 1.913 & & \\
White's Test & 2.058 & & \\
JB-stat. & 0.987 & & \\
$F$-stat. & 0.542 & & \\
$R^{2}$ & $5.097 \ddagger$ & & \\
Adjusted $R^{2}$ & 0.131 & & \\
\hline Signicat & 0.105 & & \\
\end{tabular}

significant at the 0.01 level

$\dagger$ significant at the 0.05 level

Let $M P A_{t}$ denote monetary policy action at time $t$ and define $M P A_{t}$ to take the value 1 if the monetary policy stance is changed at time $t$ and 0 otherwise. Assume that the probability of a monetary policy action conditional on the lagged change in absolute implied skewness and a set of model parameters, $\theta=\{\alpha, \beta\}$, is given by the following probit model ${ }^{13}$

$$
\operatorname{Pr}\left(M P A_{t}=1 \mid \triangle A B S S K E W_{t-1}, \theta\right)=\Phi\left(\alpha+\beta \triangle A B S S K E W_{t-1}\right)
$$

\footnotetext{
${ }^{13}$ It should be noted that this specification ignores the possibility of the ECB signalling a bias towards a policy change, for instance, two weeks before a Governing Council meeting.
} 
where $\Phi(\cdot)$ denotes the cumulative standard normal distribution function, $A B S S K E W_{t}$ denotes absolute option-implied skewness at time $t$, and $\Delta$ is the first difference operator. Estimates of the unobserved parameters, $\theta=\{\alpha, \beta\}$, in Equation (11) can be obtained via maximum likelihood.

Table 3. Maximum likelihood estimates of the probit model.

The table reports the maximum likelihood estimates of the parameters, $\theta=\{\alpha, \beta\}$, in the following probit model:

$$
\operatorname{Pr}\left(M P A_{t}=1 \mid \triangle A B S S K E W_{t-1}, \theta\right)=\Phi\left(\alpha+\beta \triangle A B S S K E W_{t-1}\right)
$$

where $\Phi(\cdot)$ denotes the cumulative standard normal distribution function, $M P A_{t}$ and $A B S S K E W_{t}$ denote monetary policy action and absolute option-implied skewness at time $t$, respectively, and $\Delta$ is the first difference operator. $M P A_{t}$ is defined to take the value 1 if the monetary policy stance was changed at time $t$ and 0 otherwise. The reported z-statistics are based on HuberWhite standard errors.

\begin{tabular}{lrrr}
\hline & Estimate & S.E. & z-stat. \\
\hline$\alpha$ & $-1.562^{\ddagger}$ & 0.139 & -11.210 \\
$\beta$ & $4.260^{\dagger}$ & 1.743 & 2.444 \\
& & & \\
Log likelihood & -49.375 & & \\
LR-stat. & $4.258{ }^{\dagger}$ & & \\
Pseudo $R^{2}$ & 0.041 & & \\
\hline
\end{tabular}

significant at the 0.01 level

${ }^{\dagger}$ significant at the 0.05 level

Table 3 reports the maximum likelihood estimates of the probit specification given in Equation (11). The reported z-statistics as well as the LR-statistic indicate that the estimated model is statistically significant. The positive coefficient for the lagged change in absolute implied skewness suggests that increasing asymmetries in bond market expectations at time $t-1$ significantly increase the probability of a monetary policy action at time $t$. The probability response curve based on the estimated probit model is plotted in Figure 3. It is apparent from Figure 3 that the probability of a monetary policy action increases with increasing asymmetries in bond market expectations. This implies that when skewness is negative and becomes more negative or is positive and becomes more positive in a given week, the probability of monetary policy action in the following week increases. 
Figure 3. Probability response curve.

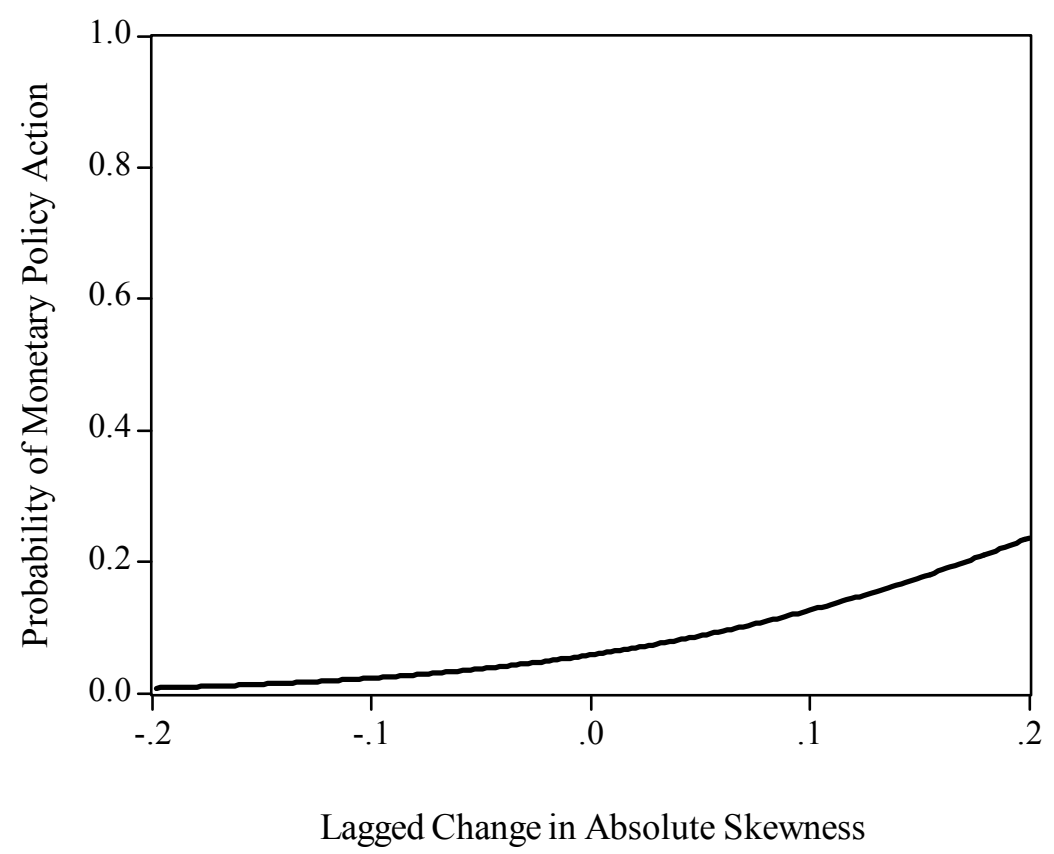

The preceding analysis has assumed that the probability of a monetary policy action is only related to the lagged change in absolute skewness. However, it is well known that short-term money market rates tend to anticipate policy changes. In order to examine whether option-implied skewness has additional explanatory power over money market rates for predicting monetary policy actions, the analysis is extended by considering lagged changes in 1-month Euribor as an additional explanatory variable. Furthermore, a possible deficiency in the probit specification given by Equation (11) is that the central bank actually has a three-choice action set, as the reference interest rates may be either increased, decreased, or kept unchanged. ${ }^{14}$ This three-choice action set can be modelled using a trinomial dummy variable. Let $M P A_{t}$ denote monetary policy action at time $t$ and define $M P A_{t}$ to take values $-1,0$, and 1 depending on whether the stance of monetary policy is loosened, unchanged, or tightened at time $t$, respectively.

\footnotetext{
${ }^{14}$ In fact, the ECB has altered the mimimum bid rate by both 25 and 50 basis points, and hence, the central bank action set could be modelled to include even five states. However, given the short sample period, three-choice action set is considered adequate.
} 
Assume $M P A_{t}$ to be related to the lagged changes in implied skewness and 1-month Euribor according to the following ordered probit specification

$$
\begin{aligned}
& \operatorname{Pr}\left(M P A_{t}=j \mid \Delta S K E W_{t-1}, \Delta r_{t-1}, \theta\right)= \\
& \qquad \begin{cases}\Phi\left(\gamma_{1}-\beta_{1} \Delta S K E W_{t-1}-\beta_{2} \Delta r_{t-1}\right) & \text { if } j=-1 \\
\Phi\left(\gamma_{2}-\beta_{1} \Delta S K E W_{t-1}-\beta_{2} \Delta r_{t-1}\right)-\Phi\left(\gamma_{1}-\beta_{1} \Delta S K E W_{t-1}-\beta_{2} \Delta r_{t-1}\right) & \text { if } j=0 \\
1-\Phi\left(\gamma_{2}-\beta_{1} \Delta S K E W_{t-1}-\beta_{2} \Delta r_{t-1}\right) & \text { if } j=1\end{cases}
\end{aligned}
$$

where $\Phi(\cdot)$ denotes the cumulative standard normal distribution function, $S K E W_{t}$ is option-implied skewness at time $t, r_{t}$ is 1 -month Euribor at time $t$, and $\Delta$ is the first difference operator. The parameters, $\theta=\left\{\gamma_{1}, \gamma_{2}, \beta_{1}, \beta_{2}\right\}$, for the ordered probit model can be estimated by maximum likelihood.

The maximum likelihood estimates of the ordered probit model are reported in Table 4. The estimated partition boundaries as well as the coefficients for the lagged changes in implied skewness and 1-month Euribor are statistically highly significant. The estimated coefficients for the lagged changes in both implied skewness and 1month Euribor are positive, indicating that increasing skewness and Euribor at time $t-1$ significantly increase the probability of monetary policy tightening at time $t$ while decreasing skewness and Euribor at time $t-1$ significantly increase the probability of monetary policy loosening at time $t$. Hence, the estimation results suggest that asymmetries in bond market expectations do have additional explanatory power over money market rates for predicting policy changes.

In summary, both the probit and ordered probit estimation results show that lagged changes in option-implied skewness have some explanatory power for monetary policy actions. Together with the statistics reported in Table 1, the estimated probit and ordered probit models suggest that if skewness is negative and becomes more negative in a given week, the probability of monetary policy loosening in the following week increases. Similarly, the results suggest that if skewness is positive and becomes more positive in a given week, the probability of monetary policy tightening in the following week increases. These estimation results imply that asymmetries in market expectations anticipate monetary policy decisions of the ECB, at least to some extent. 
Table 4. Maximum likelihood estimates of the ordered probit model.

The table reports the maximum likelihood estimates of the parameters, $\theta=\left\{\gamma_{1}, \gamma_{2}, \beta_{1}, \beta_{2}\right\}$, in the following ordered probit model:

$$
\begin{aligned}
\operatorname{Pr}\left(M P A_{t}=j \mid \Delta S K E W_{t-1}, \Delta r_{t-1}, \theta\right)= & \\
& \begin{cases}\Phi\left(\gamma_{1}-\beta_{1} \Delta S K E W_{t-1}-\beta_{2} \Delta r_{t-1}\right) & \text { if } j=-1 \\
\Phi\left(\gamma_{2}-\beta_{1} \Delta S K E W_{t-1}-\beta_{2} \Delta r_{t-1}\right)-\Phi\left(\gamma_{1}-\beta_{1} \Delta S K E W_{t-1}-\beta_{2} \Delta r_{t-1}\right) & \text { if } j=0 \\
1-\Phi\left(\gamma_{2}-\beta_{1} \Delta S K E W_{t-1}-\beta_{2} \Delta r_{t-1}\right) & \text { if } j=1\end{cases}
\end{aligned}
$$

where $\Phi(\cdot)$ denotes the cumulative standard normal distribution function, $M P A_{t}, S K E W_{t}$, and $r_{t}$ denote monetary policy action, option-implied skewness, and 1-month Euribor at time $t$, respectively, and $\Delta$ is the first difference operator. $M P A_{t}$ is defined to take values $-1,0$, and 1 depending on whether the monetary policy stance was loosened, unchanged or tightened at time $t$, respectively. The reported z-statistics are based on Huber-White standard errors.

\begin{tabular}{lrrr}
\hline & Estimate & S.E. & z-stat. \\
\hline$\gamma_{1}$ & $-2.020^{\ddagger}$ & 0.167 & -12.105 \\
$\gamma_{2}$ & $1.971^{\ddagger}$ & 0.185 & 10.662 \\
$\beta_{1}$ & $3.523^{\dagger}$ & 1.442 & 2.443 \\
$\beta_{2}$ & $4.415^{\ddagger}$ & 1.384 & 3.189 \\
& & & \\
Log likelihood & -55.414 & & \\
LR-stat. & $11.588^{\ddagger}$ & & \\
Pseudo $R^{2}$ & 0.095 & & \\
\hline
\end{tabular}

* significant at the 0.01 level

${ }^{\dagger}$ significant at the 0.05 level

\section{CONCLUSIONS}

This paper contributes to the literature on the impact of monetary policy actions on financial markets by focusing on the asymmetries in bond market expectations around monetary policy actions of the European Central Bank. The asymmetries in market expectations are measured by the skewness of option-implied probability distributions of future bond yields. In order to assess the asymmetries in market expectations, implied probability distributions are extracted from German government bond futures options under the assumption that the distribution of the underlying asset price is a mixture of lognormal distributions. This approach allows for arbitrary skewness in the optionimplied distribution, and therefore, provides a suitable framework for assessing possible asymmetries in market expectations. 
The results of this analysis show that market expectations are systematically asymmetric around monetary policy actions of the ECB. Around monetary policy tightening, option-implied yield distributions are positively skewed, indicating that market participants attach higher probabilities for sharp yield increases than for sharp decreases. Correspondingly, around loosening of the policy, implied yield distributions are negatively skewed, suggesting that markets assign higher probabilities for sharp yield decreases than for increases. These results are reasonable, given the essentially asymmetric action set of the central bank during expansive and restrictive monetary policy periods.

Furthermore, the results of this paper indicate that market expectations are significantly altered around monetary policy actions of the ECB. The analysis shows that the asymmetries in market expectations tend to increase before changes in the monetary policy stance, and to decrease afterwards. This suggests that market participants are inclined to anticipate monetary policy shifts. Finally, the results indicate that asymmetries in bond market expectations may be utilised in predicting monetary policy actions of the ECB.

In general, the results of this paper show that option-implied asymmetries can provide useful insight into market expectations. These results may be of interest, for instance, to central banks, as the assessment of possible asymmetries in market expectations may provide useful complementary information for the purposes of formulating monetary policy and, additionally, for assessing the timing of monetary policy actions. 


\section{REFERENCES}

Bahra, B. (1997). Implied risk-neutral probability density functions from option prices: theory and application. Bank of England Working Paper Series, No. 66.

Beber, A., \& Brandt, M. (2003). The effect of macroeconomic news on beliefs and preferences: evidence from the options market. NBER Working Paper Series, No. 9914.

Bhar, R., \& Chiarella, C. (2000). Expectations of monetary policy in Australia implied by the probability distribution of interest rate derivatives. European Journal of Finance, 6, 113-125.

Black, F. (1976). The pricing of commodity contracts. Journal of Financial Economics, $3,167-179$.

Black, F., \& Scholes, M. (1973). The pricing of options and corporate liabilities. Journal of Political Economy, 81, 637-659.

Bliss, R., \& Panigirtzoglou, N. (2002). Testing the stability of implied probability density functions. Journal of Banking and Finance, 26, 381-422.

Bliss, R., \& Panigirtzoglou, N. (2004). Option-implied risk aversion estimates. Journal of Finance, 59, 407-446.

Bomfim, A. (2003). Pre-announcement effects, news effects, and volatility: monetary policy and the stock market. Journal of Banking and Finance, 27, 133-152.

Campa, J., Chang, K., \& Reider, R. (1998). Implied exchange rate distributions: evidence from OTC options markets. Journal of International Money and Finance, 17, 117-160.

Chen, R., \& Scott, L. (1993). Pricing interest rate futures options with futures-style margining. Journal of Futures Markets, 13, 15-22.

Cooper, N., \& Talbot, J. (1999). The Yen/Dollar exchange rate in 1998: views from options markets. Bank of England Quarterly Bulletin, 37, 68-77.

Coutant, S., Jondau, E., \& Rockinger, M. (2001). Reading PIBOR futures options smiles: the 1997 snap election. Journal of Banking and Finance, 25, 1957-1987.

Galati, G., \& Melick, W. (2002). Central bank intervention and market expectations. BIS Papers, No. 10. 
Gasbarro, D., \& Monroe, G. (2004). The impact of monetary policy candidness on Australian financial markets. Journal of Multinational Financial Management, 14, $35-46$.

Gemmill, G., \& Saflekos, A. (2000). How useful are implied distributions? Evidence from stock-index options. Journal of Derivatives, 7, 83-98.

Gilchrist, S., \& Leahy, J. (2002). Monetary policy and asset prices. Journal of Monetary Economics, 49, 75-97.

Glatzer, E., \& Scheicher, M. (2003). Modelling the implied probability of stock market movements. European Central Bank Working Paper Series, No. 212.

Hördahl, P. (2000). Estimating the implied distribution of the future short term interest rate using the Longstaff-Schwartz model. European Central Bank Working Paper Series, No. 16.

Hördahl, P., \& Vestin, D. (2003). Interpreting implied risk-neutral densities: the role of risk premia. European Central Bank Working Paper Series, No. 274.

Jackwerth, J. (1999). Option-implied risk-neutral distributions and implied binomial trees: a literature review. Journal of Derivatives, 6, 66-82.

Jensen, G., Mercer, J., \& Johnson, R. (1996). Business conditions, monetary policy, and expected security returns. Journal of Financial Economics, 40, 213-237.

Johnson, R., Buetow, G., Jensen, G., \& Reilly, F. (2003). Monetary policy and fixed income returns. Quarterly Review of Economics and Finance, 43, 133-146.

Jondau, E., \& Rockinger, M. (2000). Reading the smile: the message conveyed by methods which infer risk neutral densities. Journal of International Money and Finance, 19, 885-915.

Kuttner, K. (2001). Monetary policy surprises and interest rates: evidence from the Fed funds futures market. Journal of Monetary Economics, 47, 523-544.

Lee, J. (2002). Federal funds rate target changes and interest rate volatility. Journal of Economics and Business, 54, 159-191.

Mandler, M. (2003). Comparing risk-neutral probability density functions implied by option prices: market uncertainty and ECB council meetings. Unpublished working paper. 
Melick, W., \& Thomas, C. (1997). Recovering an asset's implied PDF from option prices: an application to crude oil during the Gulf crisis. Journal of Financial and Quantitative Analysis, 32, 91-115.

Neumann, M., \& Wiedmann, J. (1998). The information content of German discount rate changes. European Economic Review, 42, 1667-1682.

Nikkinen, J., \& Sahlström, P. (2004). Impact of the Federal Open Market Committee's meetings and scheduled macroeconomic news on stock market uncertainty. International Review of Financial Analysis, forthcoming.

Panigirtzoglou, N., \& Skiadopoulos, G. (2004). A new approach to modelling the dynamics of implied distributions: theory and evidence from the S\&P 500 options. Journal of Banking and Finance, forthcoming.

Perez-Quiros, G., \& Sicilia, J. (2002). Is the European Central Bank (and the United States Federal Reserve) predictable? European Central Bank Working Paper Series, No. 192.

Ritchey, R. (1990). Call option valuation for discrete normal mixtures. Journal of Financial Research, 13, 285-296.

Rubinsten, M. (1994). Implied binomial trees. Journal of Finance, 49, 771-818.

Shimko, D. (1993). Bounds of Probability. Risk, 6(4), 33-37.

Söderlind, P., \& Svensson, L. (1997). New techniques to extract market expectations from financial instruments. Journal of Monetary Economics, 40, 383-429.

Söderlind, P. (2000). Market expectations in the UK before and after the ERM crisis. Economica, 67, 1-18.

Thorbecke, W. (1997). On stock market returns and monetary policy. Journal of Finance, 52, 635-654. 


\section{European Central Bank working paper series}

For a complete list of Working Papers published by the ECB, please visit the ECB's website (http://www.ecb.int).

202 "Aggregate loans to the euro area private sector" by A. Calza, M. Manrique and J. Sousa, January 2003.

203 "Myopic loss aversion, disappointment aversion and the equity premium puzzle" by D. Fielding and L. Stracca, January 2003.

204 "Asymmetric dynamics in the correlations of global equity and bond returns" by L. Cappiello, R.F. Engle and K. Sheppard, January 2003.

205 "Real exchange rate in an inter-temporal n-country-model with incomplete markets" by B. Mercereau, January 2003.

206 "Empirical estimates of reaction functions for the euro area" by D. Gerdesmeier and B. Roffia, January 2003.

207 “A comprehensive model on the euro overnight rate” by F. R. Würtz, January 2003.

208 "Do demographic changes affect risk premiums? Evidence from international data" by A. Ang and A. Maddaloni, January 2003.

209 "A framework for collateral risk control determination" by D. Cossin, Z. Huang, D. Aunon-Nerin and F. González, January 2003.

210 "Anticipated Ramsey reforms and the uniform taxation principle: the role of international financial markets” by S. Schmitt-Grohé and M. Uribe, January 2003.

2II "Self-control and savings" by P. Michel and J.P. Vidal, January 2003.

212 "Modelling the implied probability of stock market movements" by E. Glatzer and M. Scheicher, January 2003.

213 “Aggregation and euro area Phillips curves” by S. Fabiani and J. Morgan, February 2003.

2I4 "On the selection of forecasting models" by A. Inoue and L. Kilian, February 2003.

215 "Budget institutions and fiscal performance in Central and Eastern European countries" by H. Gleich, February 2003.

216 "The admission of accession countries to an enlarged monetary union: a tentative assessment” by M. Ca'Zorzi and R. A. De Santis, February 2003.

217 "The role of product market regulations in the process of structural change" by J. Messina, March 2003. 
218 "The zero-interest-rate bound and the role of the exchange rate for monetary policy in Japan" by G. Coenen and V. Wieland, March 2003.

219 "Extra-euro area manufacturing import prices and exchange rate pass-through" by B. Anderton, March 2003.

220 "The allocation of competencies in an international union: a positive analysis" by M. Ruta, April 2003.

221 "Estimating risk premia in money market rates" by A. Durré, S. Evjen and R. Pilegaard, April 2003.

222 "Inflation dynamics and subjective expectations in the United States" by K. Adam and M. Padula, April 2003.

223 "Optimal monetary policy with imperfect common knowledge" by K. Adam, April 2003.

224 "The rise of the yen vis-à-vis the ("synthetic") euro: is it supported by economic fundamentals?" by C. Osbat, R. Rüffer and B. Schnatz, April 2003.

225 "Productivity and the ("synthetic") euro-dollar exchange rate" by C. Osbat, F. Vijselaar and B. Schnatz, April 2003.

226 "The central banker as a risk manager: quantifying and forecasting inflation risks" by L. Kilian and S. Manganelli, April 2003.

227 "Monetary policy in a low pass-through environment" by T. Monacelli, April 2003.

228 "Monetary policy shocks - a nonfundamental look at the data" by M. Klaeffing, May 2003.

229 "How does the ECB target inflation?" by P. Surico, May 2003.

230 "The euro area financial system: structure, integration and policy initiatives" by P. Hartmann, A. Maddaloni and S. Manganelli, May 2003.

23I "Price stability and monetary policy effectiveness when nominal interest rates are bounded at zero" by G. Coenen, A. Orphanides and V. Wieland, May 2003.

232 "Describing the Fed's conduct with Taylor rules: is interest rate smoothing important?" by E. Castelnuovo, May 2003.

233 "The natural real rate of interest in the euro area" by N. Giammarioli and N. Valla, May 2003.

234 "Unemployment, hysteresis and transition" by M. León-Ledesma and P. McAdam, May 2003.

235 "Volatility of interest rates in the euro area: evidence from high frequency data" by N. Cassola and C. Morana, June 2003. 
236 "Swiss monetary targeting 1974-1996: the role of internal policy analysis" by G. Rich, June 2003.

237 "Growth expectations, capital flows and international risk sharing" by O. Castrén, M. Miller and R. Stiegert, June 2003.

238 "The impact of monetary union on trade prices" by R. Anderton, R. E. Baldwin and D. Taglioni, June 2003.

239 "Temporary shocks and unavoidable transitions to a high-unemployment regime" by W. J. Denhaan, June 2003.

240 "Monetary policy transmission in the euro area: any changes after EMU?" by I. Angeloni and M. Ehrmann, July 2003.

24I Maintaining price stability under free-floating: a fearless way out of the corner?" by C. Detken and V. Gaspar, July 2003.

242 "Public sector efficiency: an international comparison" by A. Afonso, L. Schuknecht and V. Tanzi, July 2003.

243 "Pass-through of external shocks to euro area inflation" by E. Hahn, July 2003.

244 "How does the ECB allot liquidity in its weekly main refinancing operations? A look at the empirical evidence” by S. Ejerskov, C. Martin Moss and L. Stracca, July 2003.

245 “Money and payments: a modern perspective” by C. Holthausen and C. Monnet, July 2003.

246 "Public finances and long-term growth in Europe - evidence from a panel data analysis" by D. R. de Ávila Torrijos and R. Strauch, July 2003.

247 "Forecasting euro area inflation: does aggregating forecasts by HICP component improve forecast accuracy?" by K. Hubrich, August 2003.

248 "Exchange rates and fundamentals" by C. Engel and K. D. West, August 2003.

249 "Trade advantages and specialisation dynamics in acceding countries" by A. Zaghini, August 2003.

250 "Persistence, the transmission mechanism and robust monetary policy" by I. Angeloni, G. Coenen and F. Smets, August 2003.

25I "Consumption, habit persistence, imperfect information and the lifetime budget constraint" by A. Willman, August 2003.

252 "Interpolation and backdating with a large information set" by E. Angelini, J. Henry and M. Marcellino, August 2003.

253 "Bond market inflation expectations and longer-term trends in broad monetary growth and inflation in industrial countries, 1880-200I” by W. G. Dewald, September 2003. 
254 "Forecasting real GDP: what role for narrow money?" by C. Brand, H.-E. Reimers and F. Seitz, September 2003.

255 "Is the demand for euro area M3 stable?" by A. Bruggeman, P. Donati and A. Warne, September 2003.

256 "Information acquisition and decision making in committees: a survey" by K. Gerling, H. P. Grüner, A. Kiel and E. Schulte, September 2003.

257 "Macroeconomic modelling of monetary policy" by M. Klaeffling, September 2003.

258 "Interest rate reaction functions and the Taylor rule in the euro area" by P. GerlachKristen, September 2003.

259 "Implicit tax co-ordination under repeated policy interactions" by M. Catenaro and J.-P. Vidal, September 2003.

260 "Aggregation-theoretic monetary aggregation over the euro area, when countries are heterogeneous" by W. A. Barnett, September 2003.

261 "Why has broad money demand been more stable in the euro area than in other economies? A literature review" by A. Calza and J. Sousa, September 2003.

262 "Indeterminacy of rational expectations equilibria in sequential financial markets" by P. Donati, September 2003.

263 "Measuring contagion with a Bayesian, time-varying coefficient model" by M. Ciccarelli and A. Rebucci, September 2003.

264 "A monthly monetary model with banking intermediation for the euro area" by A. Bruggeman and M. Donnay, September 2003.

265 "New Keynesian Phillips Curves: a reassessment using euro area data" by P. McAdam and A. Willman, September 2003.

266 "Finance and growth in the EU: new evidence from the liberalisation and harmonisation of the banking industry" by D. Romero de Ávila, September 2003.

267 "Comparing economic dynamics in the EU and CEE accession countries" by R. Süppel, September 2003.

268 "The output composition puzzle: a difference in the monetary transmission mechanism in the euro area and the US" by I. Angeloni, A. K. Kashyap, B. Mojon and D. Terlizzese, September 2003.

269 "Zero lower bound: is it a problem with the euro area?" by G. Coenen, September 2003.

270 "Downward nominal wage rigidity and the long-run Phillips curve: simulation-based evidence for the euro area" by G. Coenen, September 2003.

27I "Indeterminacy and search theory" by N. Giammarioli, September 2003. 
272 "Inflation targets and the liquidity trap" by M. Klaeffling and V. López Pérez, September 2003.

273 "Definition of price stability, range and point inflation targets: the anchoring of long-term inflation expectations" by E. Castelnuovo, S. Nicoletti-Altimari and D. RodriguezPalenzuela, September 2003.

274 "Interpreting implied risk neutral densities: the role of risk premia" by P. Hördahl and D. Vestin, September 2003.

275 "Identifying the monetary transmission mechanism using structural breaks" by A. Beyer and R. Farmer, September 2003.

276 "Short-term estimates of euro area real GDP by means of monthly data" by G. Rünstler, September 2003

277 "On the indeterminacy of determinacy and indeterminacy" by A. Beyer and R. Farmer, September 2003.

278 "Relevant economic issues concerning the optimal rate of inflation" by D. R. Palenzuela, G. Camba-Méndez and J. Á. García, September 2003.

279 "Designing targeting rules for international monetary policy cooperation” by G. Benigno and P. Benigno, October 2003.

280 “Inflation, factor substitution and growth" by R. Klump, October 2003.

28I "Identifying fiscal shocks and policy regimes in OECD countries" by G. de Arcangelis and S. Lamartina, October 2003.

282 "Optimal dynamic risk sharing when enforcement is a decision variable" by T. V. Koeppl, October 2003.

283 "US, Japan and the euro area: comparing business-cycle features” by P. McAdam, November 2003.

284 "The credibility of the monetary policy 'free lunch"' by J. Yetman, November 2003.

285 "Government deficits, wealth effects and the price level in an optimizing model" by B. Annicchiarico, November 2003.

286 "Country and sector-specific spillover effects in the euro area, the United States and Japan" by B. Kaltenhaeuser, November 2003.

287 “Consumer inflation expectations in Poland” by T. Łyziak, November 2003.

288 “Implementing optimal control cointegrated I(I) structural VAR models" by F. V. Monti, November 2003.

289 "Monetary and fiscal interactions in open economies" by G. Lombardo and A. Sutherland, November 2003. 
290 "Inflation persistence and robust monetary policy design" by G. Coenen, November 2003.

29I "Measuring the time-inconsitency of US monetary policy” by P. Surico, November 2003.

292 "Bank mergers, competition and liquidity" by E. Carletti, P. Hartmann and G. Spagnolo, November 2003.

293 “Committees and special interests” by M. Felgenhauer and H. P. Grüner, November 2003.

294 "Does the yield spread predict recessions in the euro area?" by F. Moneta, December 2003.

295 "Optimal allotment policy in the eurosystem's main refinancing operations?" by C. Ewerhart, N. Cassola, S. Ejerskov and N. Valla, December 2003.

296 "Monetary policy analysis in a small open economy using bayesian cointegrated structural VARs?" by M. Villani and A. Warne, December 2003.

297 “Measurement of contagion in banks' equity prices” by R. Gropp and G. Moerman, December 2003.

298 "The lender of last resort: a 2 I st century approach" by X. Freixas, B. M. Parigi and J.-C. Rochet, December 2003.

299 "Import prices and pricing-to-market effects in the euro area" by T. Warmedinger, January 2004.

300 "Developing statistical indicators of the integration of the euro area banking system" by M. Manna, January 2004.

301 “Inflation and relative price asymmetry" by A. Rátfai, January 2004.

302 “Deposit insurance, moral hazard and market monitoring” by R. Gropp and J. Vesala, February 2004.

303 "Fiscal policy events and interest rate swap spreads: evidence from the EU" by A. Afonso and R. Strauch, February 2004.

304 “Equilibrium unemployment, job flows and inflation dynamics” by A. Trigari, February 2004.

305 “A structural common factor approach to core inflation estimation and forecasting" by C. Morana, February 2004.

306 “A markup model of inflation for the euro area” by C. Bowdler and E. S. Jansen, February 2004.

307 "Budgetary forecasts in Europe - the track record of stability and convergence programmes" by R. Strauch, M. Hallerberg and J. von Hagen, February 2004.

308 "International risk-sharing and the transmission of productivity shocks" by G. Corsetti, L. Dedola and S. Leduc, February 2004.

309 "Monetary policy shocks in the euro area and global liquidity spillovers" by J. Sousa and A. Zaghini, February 2004.

310 "International equity flows and returns: A quantitative equilibrium approach" by R. Albuquerque, G. H. Bauer and M. Schneider, February 2004.

311 "Current account dynamics in OECD and EU acceding countries - an intertemporal approach" by M. Bussière, M. Fratzscher and G. Müller, February 2004. 
312 "Similarities and convergence in G-7 cycles" by F. Canova, M. Ciccarelli and E. Ortega, February 2004.

313 "The high-yield segment of the corporate bond market: a diffusion modelling approach for the United States, the United Kingdom and the euro area" by G. de Bondt and D. Marqués, February 2004.

314 "Exchange rate risks and asset prices in a small open economy" by A. Derviz, March 2004.

315 "Option-implied asymmetries in bond market expectations around monetary policy actions of the ECB" by S. Vähämaa, March 2004. 
